\title{
N-Desmethylclozapine, a Major Metabolite of Clozapine, Increases Cortical Acetylcholine and Dopamine Release In Vivo Via Stimulation of $M_{1}$ Muscarinic Receptors
}

\author{
Zhu Li*,', Mei Huang', Junji Ichikawa', Jin Dai' and Herbert Y Meltzer' \\ 'Psychiatry Department, Psychopharmacology Division, Vanderbilt University School of Medicine, Nashville, TN, USA
}

\begin{abstract}
The active moiety of clozapine, the prototypical antipsychotic drug, consists of clozapine and its major metabolite, N-desmethylclozapine (NDMC). Previous studies have suggested that NDMC may be more important than the patent compound itself for the improvement in cognition in patients with schizophrenia treated with clozapine. While the pharmacology of clozapine and NDMC are similar in most respects, NDMC has been shown to be an $M_{1}$ muscarinic receptor partial agonist whereas clozapine is an $M_{1}$ antagonist in vitro and in vivo. We hypothesized that NDMC may improve cognition by increasing dopamine (DA) and acetylcholine (ACh) release in medial prefrontal cortex (mPFC) via direct stimulation of $M_{1}$ receptors, whereas both NDMC and clozapine itself would do so by other mechanisms as well, and that clozapine would inhibit the MI agonist effect of NDMC. In the present study, using microdialysis in awake, freely moving rats, we found that NDMC at doses of 10 and 20, but not $5 \mathrm{mg} / \mathrm{kg}$, significantly increased DA and ACh release in the mPFC and HIP, but not in the nucleus accumbens (NAC). The $\mathrm{M}_{1}$-preferring antagonist, telenzepine (3 mg/kg), completely blocked NDMC $(10 \mathrm{mg} / \mathrm{kg})$-induced increases in cortical DA and ACh release. Clozapine $(1.25 \mathrm{mg} / \mathrm{kg})$, which by itself had no effect on DA or ACh release in the cortex, blocked NDMC ( $10 \mathrm{mg} / \mathrm{kg})$-induced $\mathrm{ACh}$, but not DA, release in the mPFC. The 5-HTIA receptor antagonist, WAY $00635(0.2 \mathrm{mg} / \mathrm{kg})$ blocked NDMC (20 mg/ $\mathrm{kg})$-induced cortical DA but not ACh release. These findings suggest that: (I) NDMC is an $M_{1}$ agonist while clozapine is an $M_{1}$ antagonist in vivo; (2) $M_{1}$ agonism of NDMC can contribute to the release of cortical ACh and DA release; (3) NDMC, because of its $M_{1}$ agonism, may more effectively treat the cognitive impairments observed in schizophrenia than clozapine itself; and (4) $M_{1}$ receptor agonism may be a valuable target for the development of drugs that can improve cognitive deficit in schizophrenia, and perhaps other neuropsychiatric disorders as well.

Neuropsychopharmacology (2005) 30, 1986- 1995. doi:I0.1038/sj.npp. I 300768; published online 18 May 2005
\end{abstract}

Keywords: N-desmethylclozapine; clozapine; dopamine; acetylcholine; muscarinic; cognition

\section{INTRODUCTION}

Acetylcholine (ACh) plays an important role in motor function and various domains of cognition, for example attention, learning, and memory (Winkler et al, 1995; Perry et al, 1999). Cholinergic dysfunction has been shown to be central to the pathophysiology of Alzheimer's disease (Cummings and Benson, 1987) and has also been postulated to contribute to the cognitive deficits of various neuropsychiatric disorders, including schizophrenia (Tandon and Greden, 1989; Sarter and Bruno, 1998). There are five known $\left(\mathrm{M}_{1}-\mathrm{M}_{5}\right)$ muscarinic acetylcholine receptors in the

*Correspondence: Dr Z Li, Psychiatry Department, Psychopharmacology Division, Vanderbilt University School of Medicine, 1601 23rd Ave S., Suite 306, Nashville, TN 37212, USA, Tel: + I 615327 724I, Fax: + I 615327 7093, E-mail: Zhu.Li@Vanderbilt.Edu

Received 24 January 2005; revised 8 April 2005; accepted II April 2005

Online publication: 12 April 2005 at http://www.acnp.org/citations/ Npp04 I 205050060/default.pdf human genome (Kubo et al, 1986; Bonner et al, 1987; Brann et al, 1993). Of these, the $\mathrm{M}_{1}$ receptor has been most closely linked to schizophrenia. The $\mathrm{M}_{1}$ receptor subtype is the most abundant of the muscarinic receptors in the cortex and hippocampus (Levey et al, 1991; Wei et al, 1994), brain regions crucial to cognitive function. Decreased $M_{1}$ receptor binding has been reported in postmortem studies of the prefrontal cortex, hippocampus, and striatum from patients with schizophrenia (Dean et al, 1996; Crook et al, 2000, 2001; Katerina et al, 2004); and decreased $\mathrm{M}_{1}$-receptor cDNA levels in the frontal cortex have also been reported (Mancama et al, 2003). This has contributed to the suggestion that enhancement of central cholinergic neurotransmission by $\mathrm{M}_{1}$ agonists might be useful to treat the cognitive impairments of schizophrenia (Sur et al, 2003; Weiner et al, 2004).

Clozapine, the prototypical atypical antipsychotic drug (APD), was the first APD shown to be effective in treating the cognitive dysfunction of schizophrenia (Hagger et al, 1993), a finding which has been replicated, and is shared 
by other compounds with a similar pharmacology, for example, olanzapine, quetiapine, risperidone, and ziprasidone (Woodward et al, 2005). Clozapine and olanzapine have been reported to have antimuscarinic properties (Herrling and Misbach-Lesenne, 1982; Bymaster et al, 1996). Clozapine has nanomolar affinity for all five cloned muscarinic receptors (Bolden et al, 1992). It has been reported to act as an antagonist at $\mathrm{M}_{1}$ receptor (Bolden $e t$ al, 1992; Zorn et al, 1994; Sur et al, 2003; Weiner et al, 2004) and $\mathrm{M}_{2 / 3 / 5}$ receptor (Bymaster et al, 1996; Michal et al, 1999). However, clozapine is also reported as $M_{1 / 2 / 4}$ partial agonist (Zorn et al, 1994; Fritze and Tilmann, 1995; Zeng et al, 1997; Olianas et al, 1997). The discrepancy from these studies may be due to the methodology difference as these experiments involved $\mathrm{CHO}$ cells. To add to the complexity, $\mathrm{N}$-desmethylclozapine (NDMC), the major active metabolite of clozapine in rodent and man (Aravagiri and Marder, 2001; Baldessarini et al, 1993; Weigmann et al, 1999), has its own unique muscarinic receptor pharmacology. Clozapine is rapidly metabolized to NDMC in rats and, thus, high serum levels of NDMC are seen after oral administration of clozapine, producing brain levels comparable to serum levels (Baldessarini et al, 1993; Weigmann et al, 1999). $\mathrm{NDMC}$ has been reported to be a potent $\mathrm{M}_{1}$ agonist in vivo (Sur et al, 2003; Weiner et al, 2004) and, like clozapine, to have high affinities for $5-\mathrm{HT}_{2 \mathrm{~A}}$ and $5-\mathrm{HT}_{2 \mathrm{C}}$, and weaker, but still significant affinities, for $\mathrm{D}_{2}$ receptors (Kuoppamaki et al, 1993, Weiner et al, 2004). This receptor-binding profile is similar to clozapine, suggesting that NDMC might have antipsychotic properties. NDMC also demonstrates a high affinity for $M_{4}$ and $M_{5}$ receptors, comparable to that observed for $M_{1}$ receptors (Weiner et al, 2004). Acute administration of NDMC, like clozapine, significantly increases c-Fos expression in the medial prefrontal cortex (mPFC) and nucleus accumbens (NAC), consistent with its atypical APD pharmacologic profile (Young et al, 1998).

Recently, Weiner et al (2004), using a cell-based functional assay, compared the effects of NDMC and clozapine on muscarinic receptors, and observed that NDMC displayed high potency and significant agonist efficacy at multiple muscarinic receptor subtypes, most notably the $M_{1}$ receptor. By contrast, clozapine behaved as an antagonist. Moreover, the $\mathrm{M}_{1}$ agonist activity of NDMC was blocked by both atropine and clozapine. Furthermore, NDMC, but not clozapine, increased the phosphorylation of mitogen-activated protein kinase (MAP kinase) in the CA1 regions of mouse HIP, a response consistent with $\mathrm{M}_{1}$ and not $\mathrm{M}_{2}-\mathrm{M}_{5}$-receptor activation (Berkeley et al, 2001). These results suggest that NDMC is a potent $\mathrm{M}_{1}$ agonist, whereas clozapine displays potent $\mathrm{M}_{1}$ antagonist actions in vivo. NDMC is the only commonly used antipsychotic agent that has been reported to have $\mathrm{M}_{1}$ agonist activity (Weiner et al, 2004).

The ability of APDs to improve some or all aspects of the cognitive deficit in schizophrenia (Meltzer and McGurk, 1999; Woodward et al, 2005) has been attributed, in part, to their ability to preferentially increase the release of dopamine (DA) (Imperato and Angelucci, 1989; Moghaddam and Bunney, 1990; Kuroki et al, 1999) and ACh in the cortex and HIP (Ichikawa et al, 2002a, b; Shirazi-Southall et al, 2002; Chung et al, 2004), while the anticholinergic activity of clozapine, olanzapine, thioridazine, and meso- ridazine has been suggested to interfere with memory (Eitan et al, 1992; Adler et al, 2002; McGurk et al, 2004). The increased DA release induced by the atypical APDs may be due, in part, to blockade of serotonin $5-\mathrm{HT}_{2 \mathrm{~A}}$ and $\mathrm{D}_{2}$ receptors, and direct or indirect stimulation of $5-\mathrm{HT}_{1 \mathrm{~A}}$ receptors (Ichikawa et al, 2001). The mechanism by which clozapine increases ACh release in the MPFC is distinct from the mechanism by which clozapine increases cortical DA release, since 5- $\mathrm{HT}_{1 \mathrm{~A}}$ receptor stimulation is not a factor in clozapine-induced ACh release (Ichikawa et al, 2002a).

In order to test the hypothesis that NDMC is an $\mathrm{M}_{1}$ agonist and that the $\mathrm{M}_{1}$-antagonist effect of clozapine may diminish the $\mathrm{M}_{1}$-agonist effect of NDMC, the present study examined the effect of NDMC alone, and following pretreatment with telenzepine, an $\mathrm{M}_{1}$-preferring antagonist (Schudt et al, 1988; Noronha-Blob et al, 1988), or low-dose clozapine, on DA and ACh release in the MPFC and, in some experiments, the NAC and HIP as well. We have previously found that telenzepine inhibited the ability of clozapine to increase DA and ACh release in rat MPFC (Ichikawa et al, 2004). We also examined the ability of WAY100635, a 5$\mathrm{HT}_{1 \mathrm{~A}}$-receptor antagonist reported to block the effects of clozapine on DA but not ACh release (Ichikawa et al, 2002a), to inhibit the effect of NDMC on MPFC DA and ACh release.

\section{MATERIALS AND METHODS}

\section{Animals}

Male Sprague-Dawley albino rats (Zivic-Miller Laboratories, Porterville, PA) weighing $250-350 \mathrm{~g}$ were housed two per cage and maintained in a controlled $12: 12$-h light/dark cycle and under constant temperature at $22^{\circ} \mathrm{C}$, with free access to food and water. Animals used in this study were cared for in accordance with the guidelines of the Institutional Animal Care and Use Committee of Vanderbilt University. 'Principles of laboratory animal care' (NIH Publication No. 85-23, revised 1985) were followed.

\section{Surgery and Microdialysis}

Rats were anesthetized with the modified Equithesin mixture $(810 \mathrm{mg}$ pentobarbital, $4.3 \mathrm{~g}$ choral hydrate, $2.12 \mathrm{mg} \mathrm{MgSO}_{4}, 14 \mathrm{ml}$ ethanol, and $29 \mathrm{ml}$ propylene glycol were dissolved in saline and the final volume was $100 \mathrm{ml}$ ), and mounted in a stereotaxic frame (Stoetling, Wood Dale, IL). Stainless guide cannula (21-gauge) with a dummy probe were placed and fixed by cranioplastic cement (Plastic One, Roanoke, VA) onto the cortex dorsal to both the mPFC and the NAC. Rats received dual probe implantation for the mPFC, NAC, or HIP (coordinates: $\mathrm{A}+3.2, \mathrm{~L}+0.8$ $\left(10^{\circ} \mathrm{C}\right.$ inclination), $\mathrm{V}-5.5 \mathrm{~mm}$; $\mathrm{A}+2.0, \mathrm{~L}+1.5$ to $+1.7, \mathrm{~V}$ $-7.5 \mathrm{~mm}$; and $\mathrm{A}+5.6, \mathrm{~L}+5.0, \mathrm{~V}-7.0 \mathrm{~mm}$, respectively, relative to bregma). The incision bar level was $3.0 \mathrm{~mm}$, according to the atlas of Paxinos and Watson (1998).

The microdialysis probes were constructed in our laboratory. A silica-glass capillary tube $(150 \mu \mathrm{m}$ o.d., $75 \mu \mathrm{m}$ i.d., Polymicro Technologies, Phoenix, AZ) was inserted through the inner bore of a $25 \mathrm{G}$ stainless tube. The stainless tube was inserted into a $28 \mathrm{G}$ Teflon tubing and then the Teflon tubing was inserted into the inner bore 
of a $18 \mathrm{G}$ stainless tube. The hollow fiber dialysis membrane (polyacrylonitrile/sodium methalylsulfonate polymer, $310 \mu \mathrm{m}$ o.d., $220 \mu \mathrm{m}$ i.d., 40000 Da cutoff, AN69HF, Hospal; CGH Medical, Lakewood, CO) was fitted over the glass capillary and into the end of the $25 \mathrm{G}$ stainless tube. This junction $(0.5 \mathrm{~mm})$ was glued with epoxy (5-Min Epoxy; Devkon, Danverse, MA, USA) after the length of the hollow dialysis fiber was cut to $3 \mathrm{~mm}$ and the tip of the membrane $(0.5 \mathrm{~mm})$ was plugged with epoxy. The length of exposed nonglued surface for dialyzing was $3 \mathrm{~mm}$.

At 3-5 days after cannulation, a dialysis probe was implanted into the mPFC and NAC under slight anesthesia with isoflurane (Metofane, Pitman-Moore, Mundelein, IL). Rats were then housed individually overnight in a dialysis cage. After the overnight perfusion at $0.4 \mu \mathrm{l} / \mathrm{min}$ of the probe, the flow was increased to $1.5 \mu \mathrm{l} / \mathrm{min}$. After $1 \mathrm{~h}$, the dialysate samples were collected every $30 \mathrm{~min}$. The perfusion medium was Dulbecco's phosphate-buffered saline solution (Sigma, St Louis, MO), including $\mathrm{Ca}^{2+}(138 \mathrm{mM}$ $\mathrm{NaCl}, 8.1 \mathrm{mM} \mathrm{Na} \mathrm{Na}_{2} \mathrm{HPO}_{4}, 2.7 \mathrm{mM} \mathrm{KCl}, 1.5 \mathrm{mM} \mathrm{KH} \mathrm{KO}_{4}$, $0.5 \mathrm{mM} \mathrm{MgCl}, 1.2 \mathrm{mM} \mathrm{CaCl} 2, \mathrm{pH}$ 7.4). No AChesterase inhibitor in the dialysate is required with this procedure (Ichikawa et al, 2002b). After stable baseline values in the dialysates were obtained, each rat received two injections, vehicle/NDMC, WAY100635/NDMC, telenzepine/NDMC, or clozapine/NDMC. The locations of the dialysis probes were verified at the end of each experiment by brain dissection. The procedures applied in these experiments were approved by the Institutional Animal Care and Use Committee of Vanderbilt University in Nashville, TN, where the present studies were completed.

\section{Biochemical Assays}

Determination of DA. Dialysate samples were directly applied onto a high-performance liquid chromatography (HPLC) with electrochemical detection, and analyzed with a Millennium chromatogram manager (Waters, Milford, MA). DA was separated (BDS Hypersil $3 \mu \mathrm{m} \mathrm{C18,} 1.0 \times 100 \mathrm{~mm}^{2}$; Keystone Scientific, Bellefonte, PA) at $35^{\circ} \mathrm{C}$ maintained by column heater (LC-22C Temperature Controller; BAS, West Lafayette, IN). The mobile phase consisted of $48 \mathrm{mM}$ anhydrous citric acid and $24 \mathrm{mM}$ sodium acetate trihydrate containing $0.5 \mathrm{mM}$ EDTA- $\mathrm{Na}_{2}, 10 \mathrm{mM} \mathrm{NaCl}, 2 \mathrm{mM}$ dodecyl sulfate sodium salt, and $17 \%(\mathrm{v} / \mathrm{v})$ acetonitrile, adjusted to $\mathrm{pH} 4.8$ with concentrated $\mathrm{NaOH}$, and was pumped $(0.05 \mathrm{ml} /$ min) by LC-10AD (Shimadzu, Kyoto, Japan). A Unijet working electrode (MF-1003, BAS) was set at $+0.58 \mathrm{~V}$ (LC-4C, BAS) vs an Ag/AgCl reference electrode. Reagents used were analytical or HPLC grade.

Determination of ACh. The method has been described previously (Ichikawa et al, 2002a). In brief, dialysate samples are directly injected onto the liquid chromatography/electrochemistry (LCEC) system assisted by a chromatography manager (Millennium; Waters, Milford, MA), and analyzed for ACh. ACh is separated on a coiled cation exchanger ACh column (analytical column) (Sepstik $10 \mathrm{~nm}$ ID $530^{\circ} \mathrm{C} 1.0 \mathrm{~nm}$; BAS, West Lafayette, IN), followed by the post-IMER (immobilized enzyme reactor) (BAS), which consists of choline oxidase (ChO)/AChesterase. ACh is hydrolyzed by AChesterase to form acetate and choline in the post-IMER, and then choline is oxidized by ChO to produce betaine and hydrogen peroxide $\left(\mathrm{H}_{2} \mathrm{O}_{2}\right) \cdot \mathrm{H}_{2} \mathrm{O}_{2}$ is detected and reduced to $\mathrm{H}_{2} \mathrm{O}$ on a Unijet amperometric detector cell with a peroxidase-redox-coated glassy carbon electrode (MF-9080; BAS), set at $+100 \mathrm{mV}$ (LC-4C; BAS) vs $\mathrm{Ag} / \mathrm{AgCl}$ reference electrode. This reduction is analyzed with the detector (LC-4C; BAS) as signal indicating ACh in the chromatogram.

Drugs. NDMC (ACADIA Pharmaceutical Inc.) and clozapine (Sandoz, East Hanover, NJ) was dissolved in a small amount of $0.1 \mathrm{M}$ tartaric acid and the $\mathrm{pH}$ was adjusted to 6-7 with $0.1 \mathrm{~N} \mathrm{NaOH.} \mathrm{WAY100635} \mathrm{(Wyeth} \mathrm{Laboratories,}$ Philadelphia, PA) and telenzepine (Research Chemical Inc.) were dissolved in deionized water. Vehicle or drugs in a volume of $1.0 \mathrm{ml} / \mathrm{kg}$ were administered subcutaneously to randomly assigned rats.

Data analysis. Mean predrug baseline levels (time -60 , time -30 , and time 0 ) were designated as $100 \%$. Following a significant overall repeated measures ANOVA (treatment $\times$ time), Fisher's protected least significant difference post hoc pairwise comparison and one-way ANOVA (StatView $^{\circledR} 4.5$ for the Macintosh) were used to determine group differences. A probability $p<0.05$ was considered significant in this study. All results are given as mean $\pm S E M$.

\section{RESULTS}

Basal extracellular DA levels in the dialysates obtained from all the rats used in this study were $1.93 \pm 0.11$ (mean \pm $\mathrm{SEM} \mathrm{fmol} / 10 \mu \mathrm{l} ; \quad N=51)$ for the $\mathrm{mPFC}, 2.28 \pm 0.09$ $($ mean \pm SEM fmol/10 $\mu \mathrm{l} ; N=45)$ for the HIP, and $15.26 \pm 0.52($ mean \pm SEM fmol $/ 20 \mu \mathrm{l} ; N=42$ ) for the NAC, respectively. Basal extracellular ACh levels in the dialysates obtained from all the rats used in this study were $7.85 \pm 0.22$ (mean \pm SEM fmol/10 $\mu \mathrm{l} ; N=40$ ) for the mPFC, $6.15 \pm 0.37$ (mean \pm SEM fmol/10 $\mu \mathrm{l} ; N=38$ ) for the HIP, and $4.28 \pm 0.65$ (mean \pm SEM fmol $/ 20 \mu \mathrm{l} ; N=45$ ) for the NAC, respectively. The $\mathrm{ACh}$ concentration in the $\mathrm{MPFC}$ or HIP was significantly higher than that in the NAC. There were no significant differences in basal extracellular DA or ACh levels between treatment groups within each region.

As shown in Figure 1, NDMC, at doses of 10 and $20 \mathrm{mg} /$ $\mathrm{kg}$, but not $5 \mathrm{mg} / \mathrm{kg}$, dose-dependently increased extracellular DA concentrations in the $\operatorname{mPFC}(\mathrm{F}(1,12)=14.77$, $p=0.0002 ; \mathrm{F}(1,11)=32.49, p<0.0001$, and $\mathrm{F}(1,10)=1.27$, $p=0.26$, respectively). NDMC, at 10 and $20 \mathrm{mg} / \mathrm{kg}$, but not $5 \mathrm{mg} / \mathrm{kg}$, also significantly increased cortical ACh release, but in a nondose-dependent manner $(\mathrm{F}(1,10)=4.18$, $p=0.04 ; \mathrm{F}(1,9)=6.8, p=0.01 ;$ and $\mathrm{F}(1,10)=2.02, p=0.16$, respectively). High doses of NDMC and clozapine produced a similar effect on DA release ( $\sim 250 \%$ over the baseline) (Kuroki et al, 1999). However, at a low dose, $5 \mathrm{mg} / \mathrm{kg}$, clozapine had a greater effect in cortical DA release than NDMC since at $5 \mathrm{mg} / \mathrm{kg}$ NDMC had no effect on DA release but clozapine produced a significant increase in DA release in the mPFC (Kuroki et al, 1999). Clozapine produced a much greater increase in ACh release than NDMC since both low $(5 \mathrm{mg} / \mathrm{kg})$ and high $(20 \mathrm{mg} / \mathrm{kg})$ doses of clozapine 

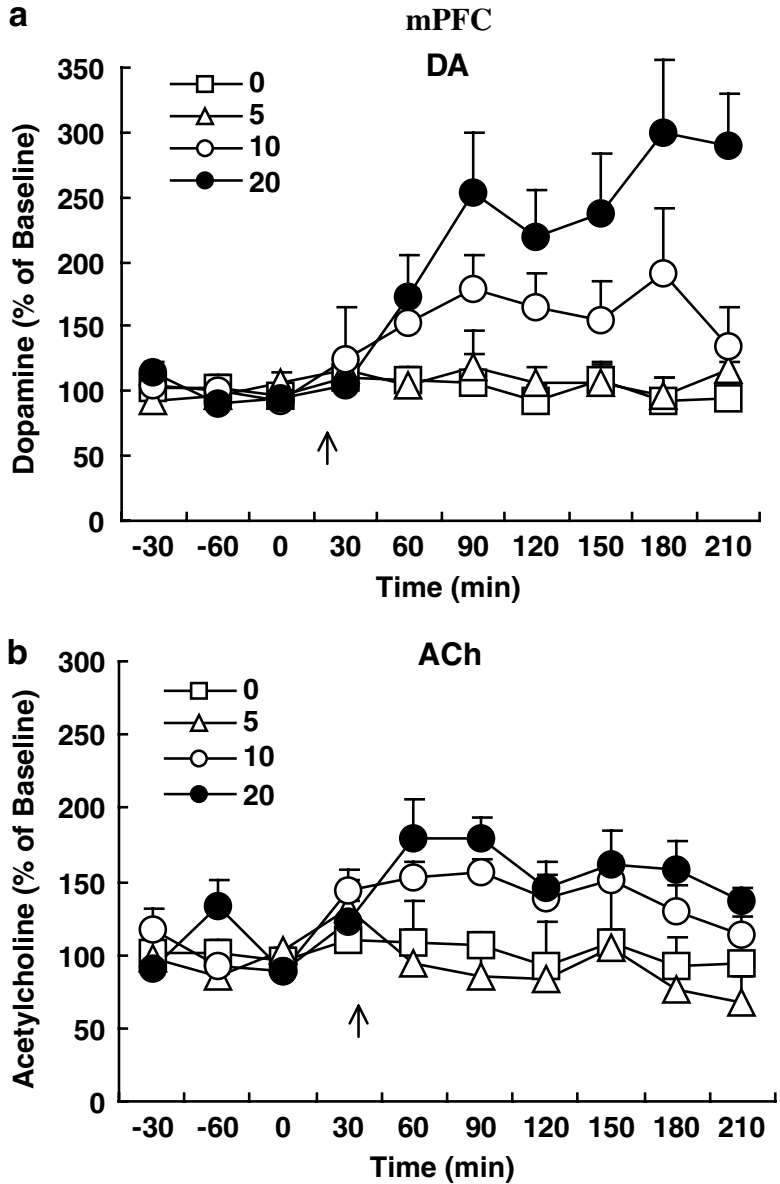

Figure I Time course effects of $\mathrm{N}$-desmethylclozapine on extracellular dopamine (a) and acetylcholine (b) levels in the medial prefrontal cortex. The arrows indicate drug injection times. Data are means \pm SEM $(N=4-7)$ of the dialysate dopamine or acetylcholine levels, expressed as a percentage of each predrug baseline dopamine or acetylcholine value.

produced a great increase in $\mathrm{ACh}$ release in the $\mathrm{mPFC}$ (Ichikawa et al, 2002b).

In the HIP, NDMC, 10 and $20 \mathrm{mg} / \mathrm{kg}$, significantly but nondose-dependently increased DA release $(\mathrm{F}(1,8)=13.54$, $p=0.0004$ and $\mathrm{F}(1,10)=13.18, p=0.004$, respectively) as well as ACh release $(\mathrm{F}(1,10)=19.48, p<0.0001$ and $\mathrm{F}(1,9)=32.83, p<0.0001$, respectively) (Figure 2). However, $5 \mathrm{mg} / \mathrm{kg}$ of NDMC did not increase either DA or ACh release in this region $(\mathrm{F}(1,7)=3.025, p=0.756$ and $\mathrm{F}(1,7)=3.339$, $p=0.705$, respectively) (Figure 2 ). In the NAC, neither 10 or $20 \mathrm{mg} / \mathrm{kg}$ of NDMC had any effect on DA $(\mathrm{F}(1,10)=0.64$, $p=0.43$ and $\mathrm{F}(1,11)=0.6, p=0.44$, respectively) or ACh release $(\mathrm{F}(1,10)=0.56, p=0.49)$ (Figure 3 ).

Telenzepine, $3 \mathrm{mg} / \mathrm{kg}$, completely blocked $10 \mathrm{mg} / \mathrm{kg}$ NDMC-induced DA (Figure 4; $\mathrm{F}(1,12)=5.71, p=0.018$ ) and $\mathrm{ACh}$ (Figure $4 ; \mathrm{F}(1,9)=38.29, p<0.0001$ ) release in the $\mathrm{mPFC}$. Clozapine, $1.25 \mathrm{mg} / \mathrm{kg}$, which itself had no effect on mPFC DA or ACh release (Figure 5), blocked NDMC $(10 \mathrm{mg} / \mathrm{kg}$ )-induced ACh (Figure $5 ; \mathrm{F}(1,9)=9.63, p=0.003$ ) but not DA (Figure 5; $\mathrm{F}(1,10)=0.0003, p=0.99$ ) release. WAY 100635 partially and significantly blocked the increased $\mathrm{mPFC}$ DA release produced by NDMC, $20 \mathrm{mg} / \mathrm{kg}$ (Figure 6; $\mathrm{F}(1,8)=4.73, p=0.03$ ), but had no effect on ACh
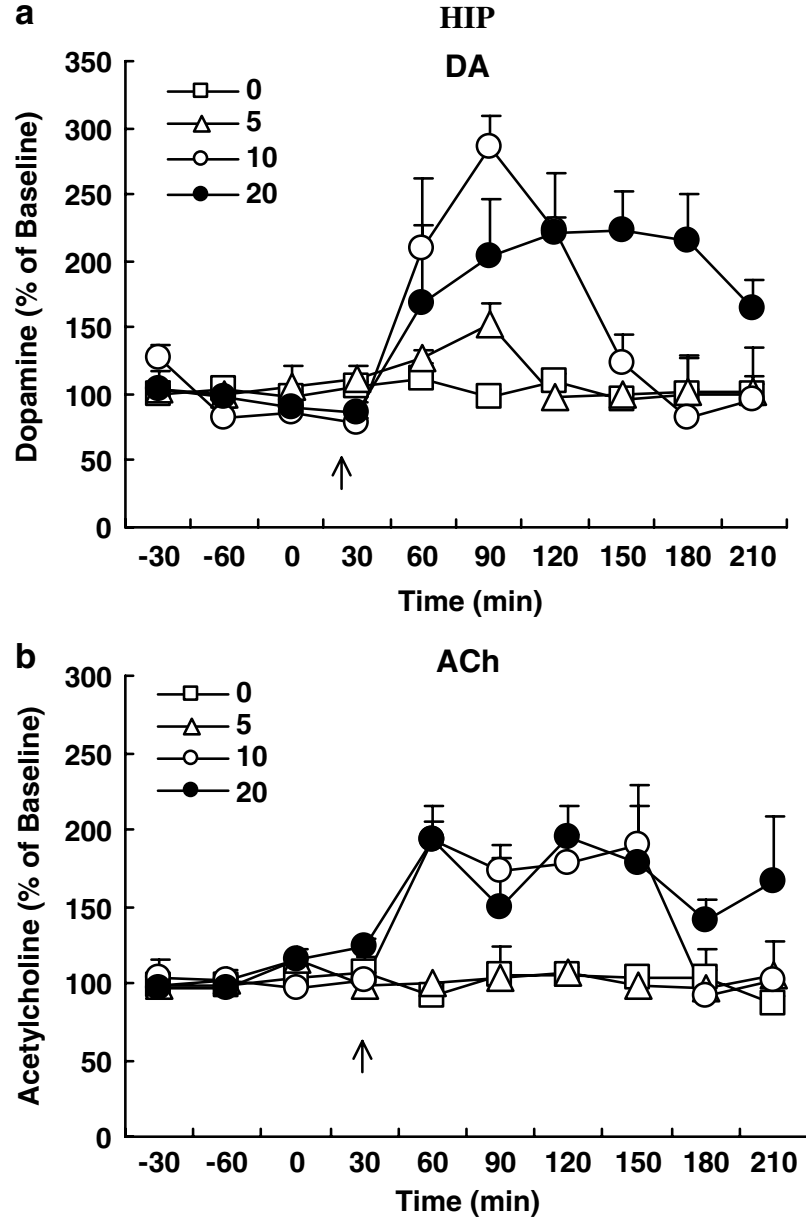

Figure 2 Time course effects of $\mathrm{N}$-desmethylclozapine on extracellular dopamine (a) and acetylcholine (b) levels in the hippocampus. The arrows indicate drug injection times. Data are means \pm SEM $(N=5-6)$ of the dialysate dopamine or acetylcholine levels, expressed as a percentage of each predrug baseline dopamine or acetylcholine value.

release produced by the same dose of NDMC (Figure 6; $\mathrm{F}(1,8)=4.73, p=0.03)$.

\section{DISCUSSION}

The main findings of the present study are that (1) NDMC, the major active metabolite of clozapine, significantly increased DA and ACh release in the MPFC and HIP, but not the NAC; (2) the $\mathrm{M}_{1}$-preferring antagonist telenzepine completely blocked DA and $\mathrm{ACh}$ release in the mPFC produced by NDMC; (3) NDMC $(10 \mathrm{mg} / \mathrm{kg})$-induced ACh release was completely blocked by clozapine $(1.25 \mathrm{mg} / \mathrm{kg})$, consistent with previous reports that NDMC is a potent $\mathrm{M}_{1}$ agonist, while clozapine has $\mathrm{M}_{1}$ antagonist properties in vivo; (4) clozapine pretreatment did not block NDMCinduced cortical DA release, indicating $\mathrm{M}_{1}$ agonism did not contribute to this effect of NDMC; and (5) the increases in DA, but not $\mathrm{ACh}$, release in the $\mathrm{mPFC}$ produced by NDMC was partially blocked by the $5-\mathrm{HT}_{1 \mathrm{~A}}$ antagonist WAY100635, indicating that cortical DA release is partially dependent upon $5-\mathrm{HT}_{1 \mathrm{~A}}$-receptor stimulation. 

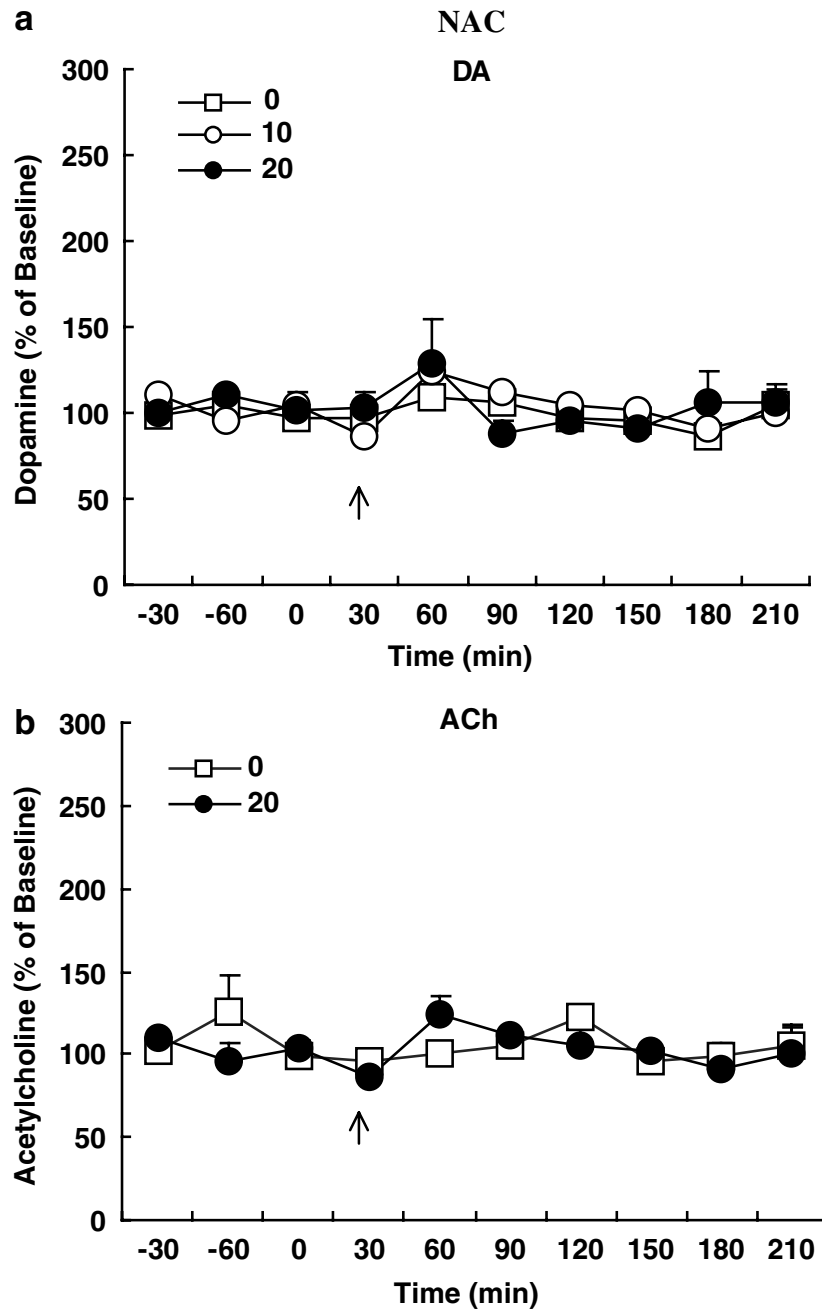

Figure 3 Time course effects of $\mathrm{N}$-desmethylclozapine on extracellular dopamine and acetylcholine levels in the nucleus accumbens. The arrows indicate drug injection times. Data are means \pm SEM $(N=4-7)$ of the dialysate dopamine levels, expressed as a percentage of each predrug baseline dopamine or acetylcholine value.

\section{Effect of NDMC on DA Release}

Like clozapine and other atypical APDs, NDMC preferentially increased DA release in the $\mathrm{MPFC}$ and HIP compared to the NAC. Low-dose NDMC $(5 \mathrm{mg} / \mathrm{kg})$ had no effect on DA release in the $\mathrm{MPFC}$, whereas the same dose of clozapine significantly increased mPFC DA release (Kuroki et al, 1999). However, NDMC and clozapine, at a dose of $20 \mathrm{mg} /$ $\mathrm{kg}$, produced similar increases in DA release. This suggests that NDMC may contribute to the ability of clozapine to increase cortical DA release in the rodent.

The fact that the increased DA release induced by NDMC in the mPFC was completely blocked by the $M_{1}$-receptor antagonist telenzepine indicates that the cortical DA release produced by NDMC is dependent upon activation of $M_{1}$ receptors. However, telenzepine also partially or completely blocked the effect of clozapine and risperidone, respectively, to increase DA release in the mPFC (Ichikawa et al, 2004). Risperidone, which has very low affinity for any muscarinic receptor subtype, is not an effective agonist at $M_{1}$ receptors (Schotte et al, 1996; Weiner et al, 2004). This suggests that
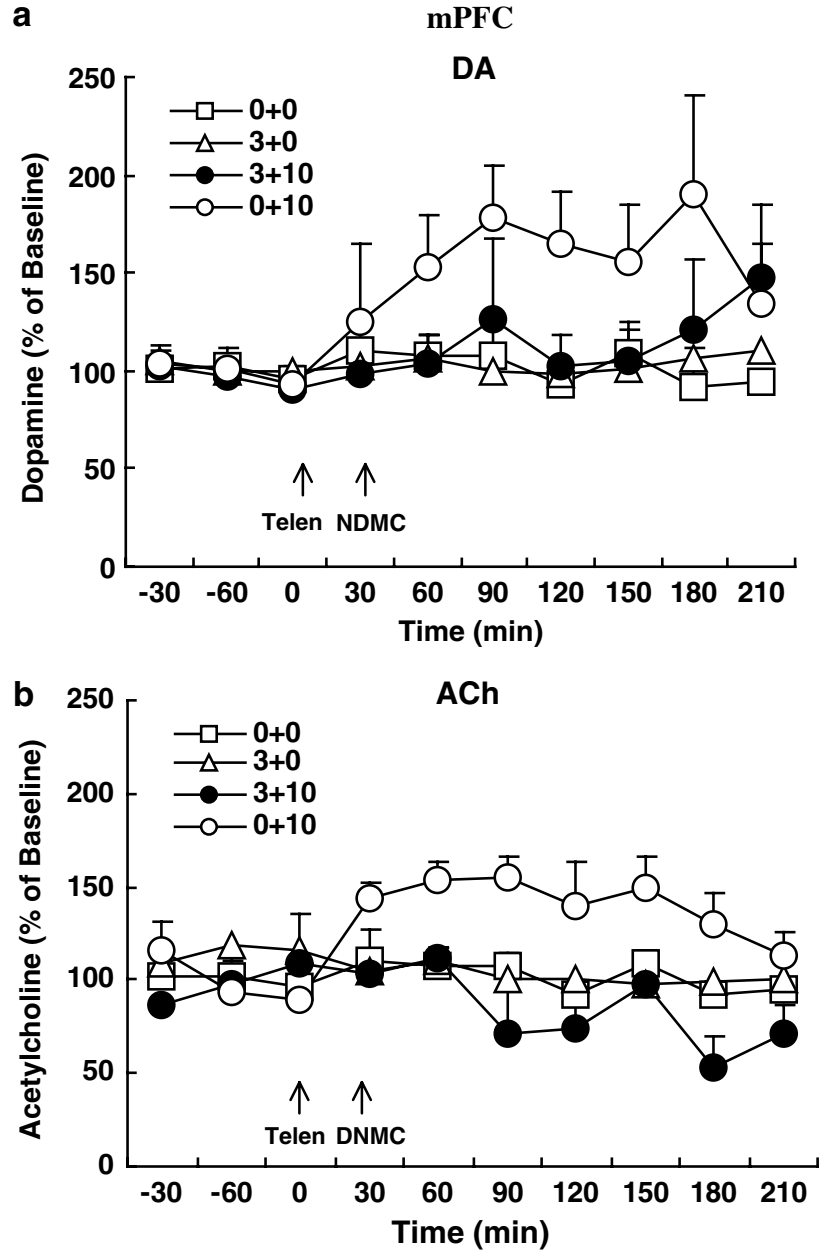

Figure 4 The effect of the $M_{1}$-receptor antagonist telenzepine $(3 \mathrm{mg} / \mathrm{kg}$, s.c.) on extracellular dopamine (a) and acetylcholine (b) release induced by $\mathrm{N}$-desmethylclozapine $(10 \mathrm{mg} / \mathrm{kg}$, s.c.) in the medial prefrontal cortex. Rats were pretreated with telenzepine $30 \mathrm{~min}$ prior to administration of $\mathrm{N}$ desmethylclozapine. The arrows indicate drug injection times. Data are means \pm SEM $(N=5-7)$ of the dialysate dopamine or acetylcholine levels, expressed as a percentage of each predrug baseline dopamine or acetylcholine value.

both NDMC and risperidone increase cortical DA release by a mechanism that is not dependent upon direct stimulation of $M_{1}$ receptors, but could involve indirect mechanism as well, and so does not prove that NDMC is acting through a direct $M_{1}$ mechanism. The same may be true for ACh release. The $M_{1}$ receptor is the primary muscarinic receptor in the human frontal, temporal, parietal, and occipital cortical areas (Flynn et al, 1995). Cortical $\mathrm{M}_{1}$ receptors are localized mainly on postsynaptic dendrites and spines associated with both glutamatergic and cholinegic transmission (Mrzljak et al, 1993). As the density of $\mathrm{M}_{1}$ receptors is much greater than $\mathrm{M}_{4}$ receptors in the cortex (Levey et al, 1991; Volpicelli and Levey, 2004), it seems more likely that the effect of atypical APDs to increase ACh release is more likely to be $\mathrm{M}_{1}$ - rather than $\mathrm{M}_{4}$-mediated. We are currently investigating whether the effect of NDMC and clozapine is cortically mediated through local injection studies.

The ability of NDMC, like clozapine, to increase cortical DA release was also partially blocked by the $5-\mathrm{HT}_{1 \mathrm{~A}^{-}}$ 
a

mPFC
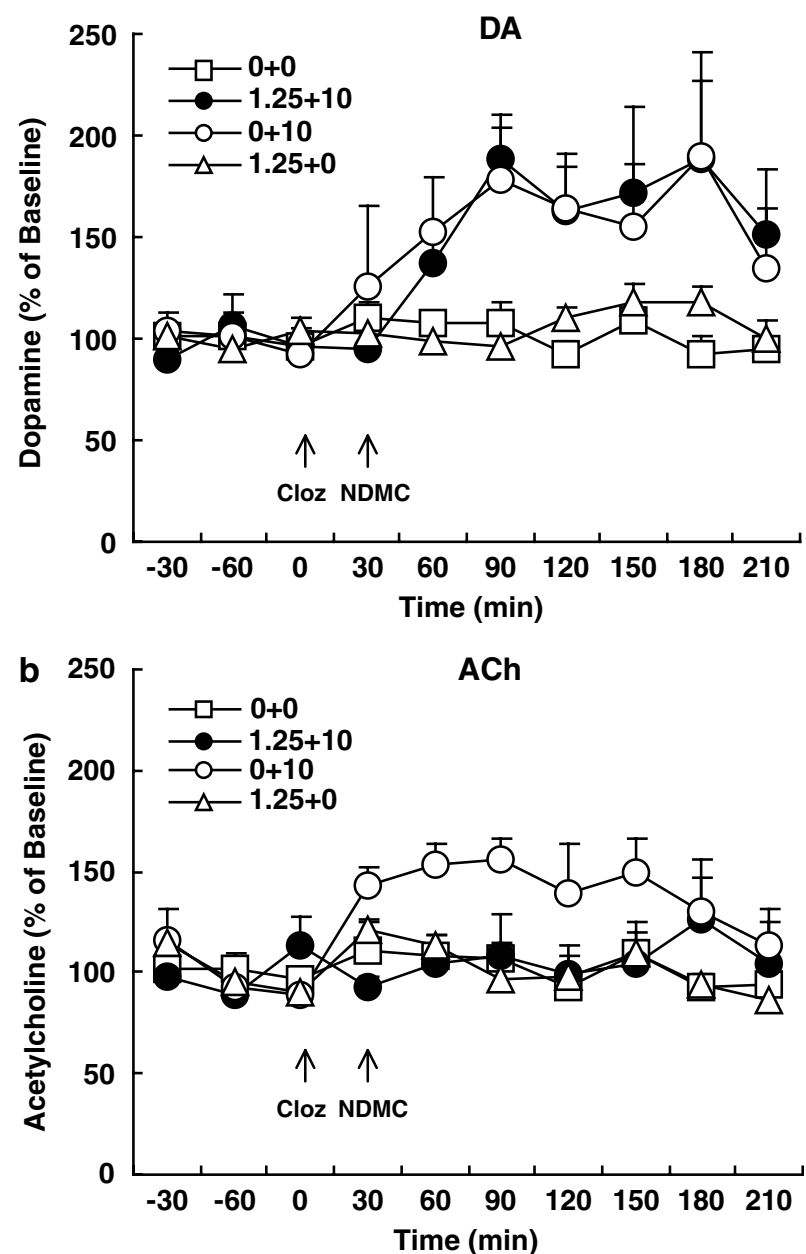

Figure 5 The effect of clozapine $(1.25 \mathrm{mg} / \mathrm{kg}$, s.c.) on extracellular dopamine (a) and acetylcholine (b) release induced by $\mathrm{N}$-desmethylclozapine $(10 \mathrm{mg} / \mathrm{kg}$, s.c.) in the medial prefrontal cortex. Rats were pretreated with clozapine $30 \mathrm{~min}$ prior to administration of $\mathrm{N}$-desmethylclozapine. The arrows indicate drug injection times. Data are means \pm SEM $(N=5-6)$ of the dialysate dopamine or acetylcholine levels, expressed as a percentage of each predrug baseline dopamine or acetylcholine value.

receptor antagonist, WAY100635. Thus, both NDMC and clozapine increase cortical DA release, in part by a $5-\mathrm{HT}_{1 \mathrm{~A}^{-}}$ dependent mechanism. NDMC has a higher affinity for the $5-\mathrm{HT}_{1 \mathrm{~A}}(111 \mathrm{nM})$ than for the $\mathrm{D}_{2}(265 \mathrm{nM})$ receptor $(\mathrm{P}$ Herrling and P Neumann, personal communication, 1989) and is most likely a $5-\mathrm{HT}_{1 \mathrm{~A}}$ partial agonist, as is clozapine. However, WAY 100635 also inhibits the increase in DA release produced by olanzapine and risperidone, neither of which are $5-\mathrm{HT}_{1 \mathrm{~A}}$ partial agonists (Ichikawa et al, 2001), suggesting an indirect mechanism that includes $5-\mathrm{HT}_{1 \mathrm{~A}}$ receptor stimulation.

NDMC also has higher affinities for the $5-\mathrm{HT}_{2 \mathrm{~A}}$ and $5-\mathrm{HT}_{2 \mathrm{C}}$ receptors than the parent compound clozapine (Kuoppamaki et al, 1993; Weiner et al, 2004). The antagonism of $5-\mathrm{HT}_{2 \mathrm{~A}}, 5-\mathrm{HT}_{2 \mathrm{C}}$ and $\mathrm{D}_{2}$ receptor by NDMC may contribute to its ability to increase DA release in the $\mathrm{mPFC}$ and HIP, as is the case for other atypical APDs (Kuroki et al, 1999; Liegeois et al, 2002; Meltzer et al, 2003). a

mPFC
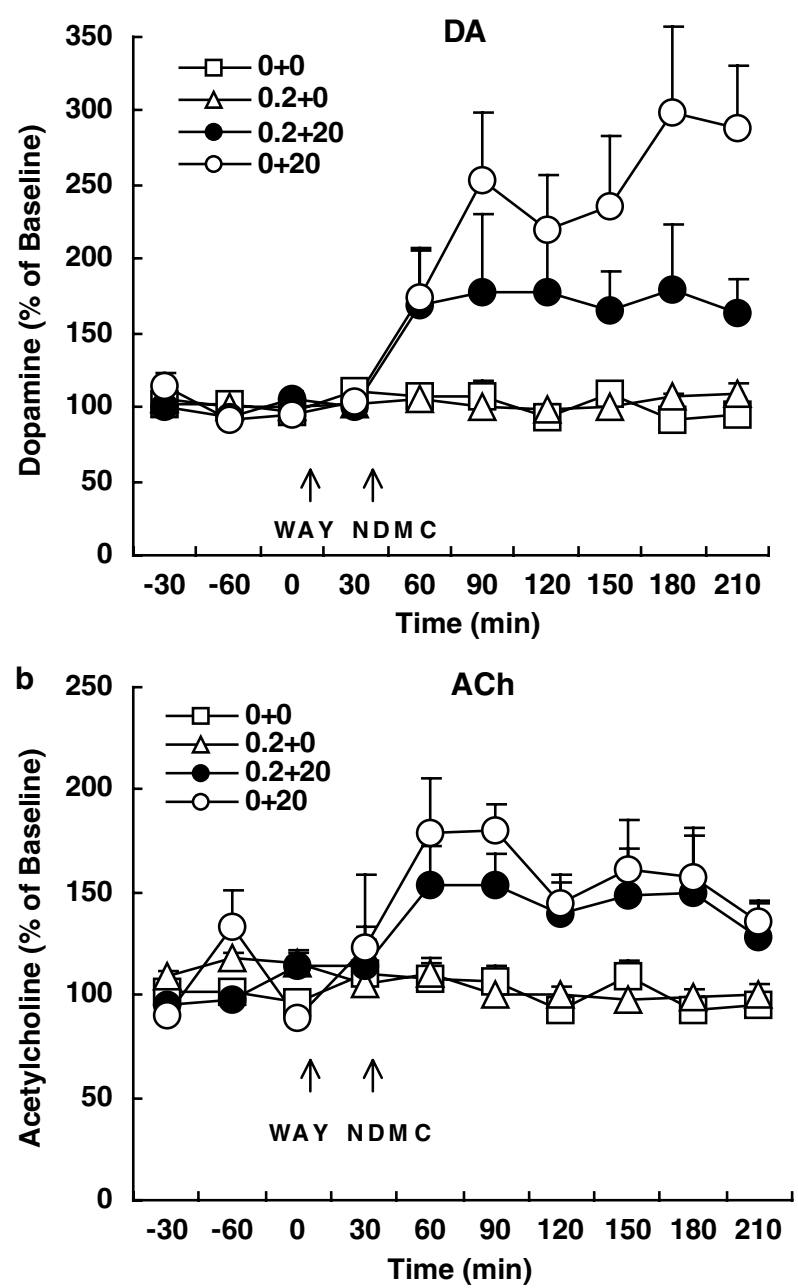

Figure 6 The effect of the 5-HT IA-receptor antagonist WAYI00635 $(0.2 \mathrm{mg} / \mathrm{kg}$, s.c.) on extracellular dopamine (a) and acetylcholine (b) release induced by $\mathrm{N}$-desmethylclozapine $(20 \mathrm{mg} / \mathrm{kg}$, s.c.) in the medial prefrontal cortex. Rats were pretreated with WAYI00635 $30 \mathrm{~min}$ prior to administration of $\mathrm{N}$-desmethylclozapine. The arrows indicate drug injection times. Data are means \pm SEM $(N=4-8)$ of the dialysate dopamine or acetylcholine levels, expressed as a percentage of each predrug baseline dopamine or acetylcholine value.

\section{Effect of NDMC on ACh Release}

NDMC, like clozapine and other atypical APDs (Ichikawa et al, 2002a), significantly increased ACh release in the mPFC and HIP, but not the NAC. The NDMC-induced ACh release in the mPFC was blocked by telenzepine but not WAY100635, as has been previously reported for clozapine and risperidone (Ichikawa et al, 2002a, 2004). This suggests that NDMC-induced cortical ACh release may be mediated by direct or indirect stimulation of $\mathrm{M}_{1}$ but not $5-\mathrm{HT}_{1 \mathrm{~A}}$ receptors. In the present study, low-dose clozapine attenuated NDMC-induced cortical Ach, but not DA release, suggesting the $\mathrm{M}_{1}$-receptor antagonism of clozapine blocked the $M_{1}$ agonism of NDMC. Therefore, the net effect of clozapine to increase cortical ACh release in vivo may be due, in part, to its metabolite NDMC, which would be partially attenuated by the $\mathrm{M}_{1}$ antagonist actions of 
clozapine. NDMC displays high potency interactions with all five human muscarinic receptors, with marked agonist activity at the $\mathrm{M}_{1}, \mathrm{M}_{4}$, and $\mathrm{M}_{5}$ receptors (Weiner et al, 2004). The $M_{1}$ receptors involved in DA and ACh release may be located on DA and ACh postsynaptic nerve terminals in the cortex, HIP, or elsewhere in the forebrain on circuits that regulate the release of these neurotransmitters by $5-\mathrm{HT}_{1 \mathrm{~A}}$ receptors as well as glutamatergic and GABAergic mechanisms. Johnson et al (2005) recently reported that intra-hippocampal infusion of $10 \mu \mathrm{M}$ clozapine and $100 \mu \mathrm{M}$ olanzapine, but not intra-septal infusion, by reverse dialysis, increased HIP ACh efflux to an extent comparable to that of systemic administration. Cholinergic neurons from the mesopontine cholinergic nuclei (Ch5, Ch6) project to the DA cell bodies in the VTA (Bymaster et al, 2002). However, mainly $M_{5}$, not $M_{1}$, muscarinic receptors are localized on these neurons (Weiner et al, 1990). Further studies are required to determine if $M_{1}$ receptors located elsewhere, for example, the ventral tegmentum, nucleus basalis Meynert, or the septum, are involved in the effect of clozapine or NDMC in enhancing cortical or HIP DA release.

Previous in vivo microdialysis studies suggest that the muscarinic autoreceptor modulating ACh efflux in the mammalian medial pontine reticular formation (Baghdoyan et al, 1998), striatum (Billard et al, 1995), and cortex (Iannazzo and Majewski, 2000; Douglas et al, 2001) is $\mathrm{M}_{2}$. Therefore, clozapine, NDMC, and olanzapine which are, to varying extents, $\mathrm{M}_{2}$ antagonists (Bymaster et al, 2002; Weiner et al, 2004), may also enhance cortical and HIP ACh release via blockade of $\mathrm{M}_{2}$ autoreceptors (Bymaster et al, 1996). Since completion of this study, Johnson et al (2005) reported that clozapine and olanzapine, $10 \mathrm{mg} / \mathrm{kg}$, produced a marked increase in extracellular ACh in the HIP while ziprasidone produced a small increase. Based upon correlation of the $\mathrm{ED}_{400 \%}$ and in vitro functional potencies at muscarinic $\mathrm{M}_{2}$ receptors, these authors concluded that the increase in $\mathrm{ACh}$ release produced by these compounds was due to $\mathrm{M}_{2}$ antagonism. It should be noted that the study of Johnson et al (2005) used neostigmine in the dialysate fluid. We have shown elsewhere that this may alter the effect of some but not all psychotropic drugs. As ziprasidone and risperidone, which lack significant $\mathrm{M}_{2}$ antagonism produce large increases in ACh release in the HIP, which are blocked by telenzepine, as is the case with clozapine (Chung et al, 2004; Ichikawa et al, 2004), we propose that $\mathrm{M}_{1}$ agonism, direct or indirect, rather than $\mathrm{M}_{2}$ antagonism, is primarily responsible for the release of $\mathrm{ACh}$ in the HIP.

\section{Clinical Significance: NDMC, $M_{1}$-Receptor Agonism and Cognition}

As previously mentioned, the $M_{1}$ receptor subtype is the most abundant of the muscarinic receptors in the cortex and hippocampus (Levey et al, 1991; Wei et al, 1994), brain regions crucial to normal cognitive function. $M_{1}$ receptors in the hippocampus have been shown to activate extracellular signal-regulated kinases (ERK), which are crucial for many neural functions, including learning, memory, and synaptic plasticity (Berkeley et al, 2001). These authors concluded that $M_{1}$ receptor-mediated ERK activation provides a mechanism by which $M_{1}$ receptors could modulate learning and memory. $\mathrm{M}_{1}$ receptor agonists have been reported to improve working memory in animals (Aura et al, 1997; McDonald et al, 1998). Muscarinc antagonists with weak specificity for the $M_{1}$ receptor may worsen working memory in patients with schizophrenia (Spohn and Strauss, 1989; King, 1990), while more specific $\mathrm{M}_{1}$ antagonists do so in laboratory animals (Bymaster et al, 1993; Roldan et al, 1997). Mice lacking $M_{1}$ receptors exhibit deficits in measures of spatial learning and memory, indicative of impaired hippocampal and cortical function (Anagnostaras et al, 2003). Learning deficits in the radial arm maze and fear-conditioning paradigm have also been reported in $\mathrm{M}_{1}$-knockout mice (Miyakawa et al, 2001). Moreover, $\mathrm{M}_{1}$-deficient mice have significantly elevated DA neurotransmission in the striatum (Gerber et al, 2001), significantly increased locomotor activity and increased response to the stimulatory effects of amphetamine, evidence of an inhibitory effect of the $M_{1}$ receptor on dopaminergic transmission, which suggests a possible basis for an antipsychotic effect of $\mathrm{M}_{1}$ agonists. As previously mentioned, the $M_{1 / 4}$ agonist xanomeline has been reported to mimic the effect of $\mathrm{D}_{2}$ antagonists to produce an antipsychotic-like profile in rats (Stanhope et al, 2001). It has been reported that NDMC dose-dependently potentiated NMDA receptor currents in CA1 pyramidal cells by 53\% (Sur et al, 2003). Decreased glutamatergic activity in pyramidal neurons has been hypothesized to be a major factor in the pathophysiology of schizophrenia (Moghaddam, 2004; Javitt, 2004). Thus, the $M_{1}$ agonism of NDMC may, by stimulating glutamatergic activity, be of particular importance to the beneficial effects of NDMC and the parent compound, clozapine, on cortical function. Patients with schizophrenia who are heterozygous for the C267A polymorphism (267C/A) of the $M_{1}$ receptor have been reported to produce more correct responses and less perseverative errors on the Wisconsin Card Sort test, which is dependent upon prefrontal cortical function (Morice, 1990; Berman et al, 1995), than those who were homozygous for $267 \mathrm{C} / \mathrm{C}$, providing additional genetic evidence suggesting that $M_{1}$ receptors have an important effect on prefrontal cortical function (Liao et al, 2003).

The effect of clozapine on DA or ACh release is most likely the result of the combined effect of clozapine and NDMC, the agonist/antagonist mixing. Thus, high NDMC levels, and particularly high NDMC/clozapine ratios, would increase $M_{1}$ muscarinic receptor stimulation, as predicted by mass action and by agonist/antagonist mixing studies (Brauner-Osborne et al, 1996). Brain clozapine concentrations in the rat during chronic treatment have been reported to exceed those of NDMC during chronic treatment by three-fold (Weigmann et al, 1999). There is no information on what the relative levels are in man. High concentrations of NDMC are found in plasma samples in some patients treated with clozapine (Hasegawa et al, 1993). High NDMC levels, and a high NDMC/clozapine ratio even more so, would increase $M_{1}$ muscarinic receptor stimulation. The present data on the blockade of NDMC-induced ACh release by clozapine are consistent with clinical data from our laboratory, which suggest that the $\mathrm{NDMC/clozapine} \mathrm{ratio} \mathrm{is}$ a better predictor of clinical response to clozapine than clozapine levels alone (Frazier et al, 2003; Mauri et al, 2003; Weiner et al, 2004). 
In conclusion, NDMC preferentially increased DA and ACh release in the mPFC and HIP but not the NAC, similar to the effect of clozapine and other atypical APDs. The blockade of NDMC-induced ACh release by telezenpine and clozapine indicates that the stimulation of $M_{1}$ receptors contributes to the ability of NDMC to increase cortical DA and ACh release, confirming that NDMC has significant $\mathrm{M}_{1}$ agonistic actions, whereas the parent compound, clozapine, is an antagonist.

\section{ACKNOWLEDGEMENTS}

This work was supported, in part, by grants from the Ritter Foundation, the William K Warren Foundation, NARSAD, and Acadia Pharmaceuticals Inc.

\section{REFERENCES}

Adler G, Grieshaber S, Faude V, Thebaldi B, Dressing H (2002). Clozapine in patients with chronic schizophrenia: serum level, EEG and memory performance. Pharmacopsychiatry 35: 190-194.

Anagnostaras SG, Murphy GG, Hamilton SE, Mitchell SL, Rahnama NP, Nathanson NM et al (2003). Selective cognitive dysfunction in acetylcholine M1 muscarinic receptor mutant mice. Nat Neurosci 6: 51-58.

Aravagiri M, Marder SR (2001). Simultaneous determination of clozapine and its $\mathrm{N}$-desmethyl and $\mathrm{N}$-oxide metabolites in plasma by liquid chromatography/electrospray tandem mass spectrometry and its application to plasma level monitoring in schizophrenic patients. J Pharm Biomed Anal 26: 301-311.

Aura J, Sirvio J, Riekkinen Jr P (1997). Methoctramine moderately improves memory but pirenzepine disrupts performance in delayed non-matching to position test. Eur J Pharmacol 333: 129-134.

Baghdoyan HA, Lydic R, Fleegal MA (1998). M2 muscarinic autoreceptors modulate acetylcholine release in the medial pontine reticular formation. J Pharmacol Exp Ther 286: 1446-1452.

Baldessarini RJ, Centorrino F, Flood JG, Volpicelli SA, HustonLyons D, Cohen BM (1993). Tissue concentrations of clozapine and its metabolites in the rat. Neuropsychopharmacology 9: $117-124$

Berkeley JL, Gomeza J, Wess J, Hamilton SE, Nathanson NM, Levey AI (2001). M1 muscarinic acetylcholine receptors activate extracellular signal-regulated kinase in CA1 pyramidal neurons in mouse hippocampal slices. Mol Cell Neurosci 18: 512-524.

Berman KF, Ostrem JL, Randolph C, Gold J, Goldberg TE, Coppola $\mathrm{R}$ et al (1995). Physiological activation of a cortical network during performance of the Wisconsin Card Sorting Test: a positron emission tomography study. Neuropsychologia 33: 1027-1046.

Billard W, Binch III H, Crosby G, McQuade RD (1995). Identification of the primary muscarinic autoreceptor subtype in rat striatum as $\mathrm{m} 2$ through a correlation of in vivo microdialysis and in vitro receptor binding data. J Pharmacol Exp Ther 273: 273-279.

Bolden C, Cusack B, Richelson E (1992). Antagonism by antimuscarinic and neuroleptic compounds at the five cloned human muscarinic cholinergic receptors expressed in Chinese hamster ovary cells. J Pharmacol Exp Ther 260: 576-580.

Bonner TI, Buckley NJ, Young AC, Brann MR (1987). Identification of a family of muscarinic acetylcholine receptor genes. Science 237: $527-532$.
Brann MR, Ellis J, Jorgensen H, Hill-Eubanks D, Jones SV (1993). Muscarinic acetylcholine receptor subtypes: localization and structure/function. Prog Brain Res 98: 121-127.

Brauner-Osborne H, Ebert B, Brann MR, Falch E, KrogsgaardLarsen P (1996). Functional partial agonism at cloned human muscarinic acetylcholine receptors. Eur J Pharmacol 313: 145-150.

Bymaster FP, Calligaro DO, Falcone JF, Marsh RD, Moore NA, Tye NC et al (1996). Radioreceptor binding profile of the atypical antipsychotic olanzapine. Neuropsychopharmacology 14: 87-96.

Bymaster FP, Felder C, Ahmed S, McKinzie D (2002). Muscarinic receptors as a target for drugs treating schizophrenia. Curr Drug Targets - CNS Neurol Dis 1: 163-181.

Bymaster FP, Heath I, Hendrix JC, Shannon HE (1993). Comparative behavioral and neurochemical activities of cholinergic antagonists in rats. J Pharmacol Exp Ther 267: 16-24.

Chung YC, Li Z, Dai J, Meltzer HY, Ichikawa J (2004). Clozapine increases both acetylcholine and dopamine release in rat ventral hippocampus: role of 5-HT1A receptor agonism. Brain Res 1023: 54-63.

Crook JM, Tomaskovic-Crook E, Copolov DL, Dean B (2000). Decreased muscarinic receptor binding in subjects with schizophrenia: a study of the human hippocampal formation. Biol Psychiatry 48: 381-388.

Crook JM, Tomaskovic-Crook E, Copolov DL, Dean B (2001). Low muscarinic receptor binding in prefrontal cortex from subjects with schizophrenia: a study of Brodmann's areas $8,9,10$, and 46 and the effects of neuroleptic drug treatment. Am J Psychiatry 158: $918-925$.

Cummings JL, Benson DF (1987). The role of the nucleus basalis of Meynert in dementia: review and reconsideration. Alzheimer Dis Associated Disord 1: 128-155.

Dean B, Crook JM, Opeskin K, Hill C, Keks N, Copolov DL (1996). The density of muscarinic M1 receptors is decreased in the caudate-putamen of subjects with schizophrenia. Mol Psychiatry 1: $54-58$

Douglas CL, Baghdoyan HA, Lydic R (2001). M2 muscarinic autoreceptors modulate acetylcholine release in prefrontal cortex of C57BL/6J mouse. J Pharmacol Exp Ther 299: 960-966.

Eitan N, Levin Y, Ben-Artzi E, Levy A, Neumann M (1992). Effects of antipsychotic drugs on memory functions of schizophrenic patients. Acta Psychiatr Scand 85: 74-76.

Flynn DD, Ferrari-DiLeo G, Mash DC, Levey AI (1995). Differential regulation of molecular subtypes of muscarinic receptors in Alzheimer's disease. J Neurochem 64: 1888-1891.

Frazier JA, Cohen LG, Jacobsen L, Grothe D, Flood J, Baldessarini $\mathrm{RJ}$ et al (2003). Clozapine pharmacokinetics in children and adolescents with childhood-onset schizophrenia. J Clin Psychopharmacol 23: 87-91.

Fritze J, Tilmann E (1995). Pirenzepine for clozapine-induced hypersalivation. Lancet 346: 1034.

Gerber DJ, Sotnikova TD, Gainetdinov RR, Huang SY, Caron MG, Tonegawa S (2001). Hyperactivity, elevated dopaminergic transmission, and response to amphetamine in M1 muscarinic acetylcholine receptor-deficient mice. Proc Natl Acad Sci USA 98: 15312-15317.

Hagger C, Buckley P, Kenny JT, Friedman L, Ubogy D, Meltzer HY (1993). Improvement in cognitive functions and psychiatric symptoms in treatment-refractory schizophrenic patients receiving clozapine. Biol Psychiatry 34: 702-712.

Hasegawa M, Gutierrez-Esteinou R, Way L, Meltzer HY (1993). Relationship between clinical efficacy and clozapine plasma concentrations in schizophrenia: effect of smoking. J Clin Psychopharmacol 13: 383-390.

Herrling PL, Misbach-Lesenne B (1982). Effects of clozapine in a selective muscarinic bioassay and on single cells of the rat hippocampus. Naunyn-Schmiedebergs Arch Pharmacol 320: $20-25$. 
Iannazzo L, Majewski H (2000). M(2)/M(4)-muscarinic receptors mediate automodulation of acetylcholine outflow from mouse cortex. Neurosci Lett 287: 129-132.

Ichikawa J, Chung Y, Li Z, Dai J, Huang M, Meltzer HY (2004). Telenzepine, a muscarinic M1/4 antagonist, blocks the ability of clozapine and risperidone to increase cortical acetylcholine and dopamine release: role of M1/4 agonism in schizophrenia. Program No. 950.13. 2004 Abstract Viewer/Itinerary Planner. Soc Neuroscience.

Ichikawa J, Dai J, Meltzer HY (2002a). 5-HT(1A) and 5-HT(2A) receptors minimally contribute to clozapine-induced acetylcholine release in rat medial prefrontal cortex. Brain Res 939: 34-42.

Ichikawa J, Dai J, O’Laughlin IA, Fowler WL, Meltzer HY (2002b). Atypical, but not typical, antipsychotic drugs increase cortical acetylcholine release without an effect in the nucleus accumbens or striatum. Neuropsychopharmacology 26: 325-339.

Ichikawa J, Ishii $\mathrm{H}$, Bonaccorso S, Fowler WL, O'Laughlin IA, Meltzer HY (2001). 5-HT(2A) and D(2) receptor blockade increases cortical DA release via $5-\mathrm{HT}(1 \mathrm{~A})$ receptor activation: a possible mechanism of atypical antipsychotic-induced cortical dopamine release. J Neurochem 76: 1521-1531.

Imperato A, Angelucci L (1989). The effects of clozapine and fluperlapine on the in vivo release and metabolism of dopamine in the striatum and in the prefrontal cortex of freely moving rats. Psychopharmacol Bull 25: 383-389.

Javitt DC (2004). Glutamate as a therapeutic target in psychiatric disorders. Mol Psychiatry 9: 984-997.

Johnson DE, Nedza FM, Spracklin DK, Ward KM, Schmidt AW, Iredale PA et al (2005). The role of muscarinic receptor antagonism in antipsychotic-induced hippocampal acetylcholine release. Eur J Pharmacol 506: 209-219.

Katerina Z, Andrew K, Filomena M, Xu-Feng H (2004). Investigation of $\mathrm{ml} / \mathrm{m} 4$ muscarinic receptors in the anterior cingulate cortex in schizophrenia, bipolar disorder, and major depression disorder. Neuropsychopharmacology 29: 619-625.

King DJ (1990). The effect of neuroleptics on cognitive and psychomotor function. Br J Psychiatry 157: 799-811.

Kubo T, Fukuda K, Mikami A, Maeda A, Takahashi H, Mishina M et al (1986). Cloning, sequencing and expression of complementary DNA encoding the muscarinic acetylcholine receptor. Nature 323: 411-416.

Kuoppamaki M, Syvalahti E, Hietala J (1993). Clozapine and $N$ desmethylclozapine are potent 5-HT1C receptor antagonists. Eur J Pharmacol 245: 179-182.

Kuroki T, Meltzer HY, Icikawa J (1999). Effects of antipsychotic drugs on extracellular dopamine levels in rat medial prefrontal cortex and nucleus accumbens. J Pharmacol Exp Ther 288: 774-781.

Levey AI, Kitt CA, Simonds WF, Price DL, Brann MR (1991). Identification and localization of muscarinic acetylcholine receptor proteins in brain with subtype-specific antibodies. J Neurosci 11: 3218-3226.

Liao DL, Hong CJ, Chen HM, Chen YE, Lee SM, Chang CY et al (2003). Association of muscarinic $\mathrm{ml}$ receptor genetic polymorphisms with psychiatric symptoms and cognitive function in schizophrenic patients. Neuropsychobiology 48: 72-76.

Liegeois JF, Ichikawa J, Meltzer HY (2002). 5-HT(2A) receptor antagonism potentiates haloperidol-induced dopamine release in rat medial prefrontal cortex and inhibits that in the nucleus accumbens in a dose-dependent manner. Brain Res 947: 157-165.

Mancama D, Arranz MJ, Landau S, Kerwin R (2003). Reduced expression of the muscarinic 1 receptor cortical subtype in schizophrenia. Am J Med Genet 119B: 2-6.

Mauri MC, Volonteri LS, Dell'Osso B, Regispani F, Papa P, Baldi M et al (2003). Predictors of clinical outcome in schizophrenic patients responding to clozapine. J Clin Psychopharmacol 23 660-6664.
McDonald MP, Willard LB, Wenk GL, Crawley JN (1998). Coadministration of galanin antagonist M40 with a muscarinic M1 agonist improves delayed nonmatching to position choice accuracy in rats with cholinergic lesions. J Neurosci 18: 5078-5085.

McGurk SR, Lee MA, Jayathilake K, Meltzer HY (2004). Cognitive effects of olanzapine treatment in schizophrenia. Med Gen Med 6: 27.

Meltzer HY, Li Z, Kaneda Y, Ichikawa J (2003). Serotonin receptors: their key role in drugs to treat schizophrenia. Prog Neuro-Psychopharmacol Biol Psychiatry 27: 1159-1172.

Meltzer HY, McGurk SR (1999). The effects of clozapine, risperidone, and olanzapine on cognitive function in schizophrenia. Schizophr Bull 25: 233-255.

Michal P, Lysikova M, El-Fakahany EE, Tucek S (1999). Clozapine interaction with the M2 and M4 subtypes of muscarinic receptors. Eur J Pharmacol 376: 119-125.

Miyakawa T, Yamada M, Duttaroy A, Wess J (2001). Hyperactivity and intact hippocampus-dependent learning in mice lacking the M1 muscarinic acetylcholine receptor. J Neurosci 21: 5239-5250.

Moghaddam B (2004). Targeting metabotropic glutamate receptors for treatment of the cognitive symptoms of schizophrenia. Psychopharmacology 174: 39-44.

Moghaddam B, Bunney BS (1990). Acute effects of typical and atypical antipsychotic drugs on the release of dopamine from prefrontal cortex, nucleus accumbens, and striatum of the rat: an in vivo microdialysis study. J Neurochem 54: 1755-1760.

Morice R (1990). Cognitive inflexibility and pre-frontal dysfunction in schizophrenia and mania. Br J Psychiatry 157: 50-54.

Mrzljak L, Levey AI, Goldman-Rakic PS (1993). Association of m1 and $\mathrm{m} 2$ muscarinic receptor proteins with asymmetric synapses in the primate cerebral cortex: morphological evidence for cholinergic modulation of excitatory neurotransmission. PNAS 90: 5194-5198.

Noronha-Blob L, Canning B, Costello D, Kinnier WJ (1988). Selective agents for muscarinic receptors linked to phosphoinositide breakdown. Eur J Pharmacol 154: 161-167.

Olianas MC, Maullu C, Onali P (1997). Effects of clozapine on rat striatal muscarinic receptors coupled to inhibition of adenylyl cyclase activity and on the human cloned $\mathrm{m} 4$ receptor. $\mathrm{Br} J$ Pharmacol 122: 401-408.

Paxinos G, Watson C (1998). The Rat Brain in Stereotaxxic Coordinates. Academic Press: New York.

Perry E, Walker M, Grace J, Perry R (1999). Acetylcholine in mind: a neurotransmitter correlate of consciousness? Trends Neurosci 22: $273-280$.

Roldan G, Bolanos-Badillo E, Gonzalez-Sanchez H, Quirarte GL, Prado-Alcala RA (1997). Selective M1 muscarinic receptor antagonists disrupt memory consolidation of inhibitory avoidance in rats. Neurosci Lett 230: 93-96.

Sarter M, Bruno JP (1998). Cortical acetylcholine, reality distortion, schizophrenia, and Lewy Body Dementia: too much or too little cortical acetylcholine? Brain Cognition 38: 297-316.

Schotte A, Janssen PF, Gommeren W, Luyten WH, Van Gompel P, Lesage AS et al (1996). Risperidone compared with new and reference antipsychotic drugs: in vitro and in vivo receptor binding. Psychopharmacology 124: 57-73.

Schudt C, Auriga C, Kinder B, Birdsall NJ (1988). The binding of $[3 \mathrm{H}]$ telenzepine to muscarinic acetylcholine receptors in calf forebrain. Eur J Pharmacol 145: 87-90.

Shirazi-Southall S, Rodriguez DE, Nomikos GG (2002). Effects of typical and atypical antipsychotics and receptor selective compounds on acetylcholine efflux in the hippocampus of the rat. Neuropsychopharmacology 26: 583-594.

Spohn HE, Strauss ME (1989). Relation of neuroleptic and anticholinergic medication to cognitive functions in schizophrenia. J Abnorm Psychol 98: 367-380. 
Stanhope KJ, Mirza NR, Bickerdike MJ, Bright JL, Harrington NR, Hesselink MB et al (2001). The muscarinic receptor agonist xanomeline has an antipsychotic-like profile in the rat. $J$ Pharmacol Exp Ther 299: 782-792.

Sur C, Mallorga PJ, Wittmann M, Jacobson MA, Pascarella D, Williams JB et al (2003). $N$-desmethylclozapine, an allosteric agonist at muscarinic 1 receptor, potentiates $N$-methyl-Daspartate receptor activity. Proc Natl Acad Sci USA 100: 1367413679.

Tandon R, Greden JF (1989). Cholinergic hyperactivity and negative schizophrenic symptoms. A model of cholinergic/ dopaminergic interactions in schizophrenia. Arch Gen Psychiatry 46: 745-753.

Volpicelli LA, Levey AI (2004). Muscarinic acetylcholine receptor subtpes in cerebral cortex and hippocampus. Prog Brain Res 145: $59-66$.

Wei J, Walton EA, Milici A, Buccafusco JJ (1994). m1-m5 muscarinic receptor distribution in rat CNS by RT-PCR and HPLC. J Neurochem 63: 815-821.

Weigmann H, Hartter S, Fischer V, Dahmen N, Hiemke C (1999). Distribution of clozapine and desmethylclozapine between blood and brain in rats. Eur Neuropsychopharmacol 9: 253-256.
Weiner DM, Levey AI, Brann MR (1990). Expression of muscarinic acetylcholine and dopamine receptor mRNAs in rat basal ganglia. PNAS 87: 7050-7054.

Weiner DM, Meltzer HY, Veinbergs I, Donohue EM, Spalding TA, Smith TT et al (2004). The role of M1 muscarinic receptor agonism of $\mathrm{N}$-desmethylclozapine in the unique clinical effects of clozapine. Psychopharmacology (Berl) 177: 207-216.

Winkler J, Suhr ST, Gage FH, Thal LJ, Fisher LJ (1995). Essential role of neocortical acetylcholine in spatial memory. Nature 375: 484-487.

Woodward ND, Purdon SE, Meltzer HY, Zald DH (2005). A metaanalysis of neuropsychological change to clozapine, olanzapine, quetiapine, and risperidone in schizophrenia. Int J Neuropsychopharmacol March 23: 1-16 [Epub ahead of print].

Young CD, Meltzer HY, Deutch AY (1998). Effects of desmethylclozapine on Fos protein expression in the forebrain: in vivo biological activity of the clozapine metabolite. Neuropsychopharmacology 19: 99-103.

Zeng XP, Le F, Richelson E (1997). Muscarinic m4 receptor activation by some atypical antipsychotic drugs. Eur J Pharmacol 321: 349-354.

Zorn SH, Jones SB, Ward KM, Liston DR (1994). Clozapine is a potent and selective muscarinic M4 receptor agonist. Eur J Pharmacol 269: R1-R2. 